\title{
SEJARAH DAKWAH RASULULLAH SAW DI MEKAH DAN MADINAH
}

\author{
Patmawati
}

\begin{abstract}
Abstrak
Rasulullah saw membekali diri dengan kebaikan, ketaqwaan, keikhlasan dan akhlak mulia dalam membimbing sehingga menimbulkan simpati dan audien mudah menerima ajakan (ajaran Islam). metode yang dilakukan nabi dalam dakwah secara terang-terangan adalah: pertama, mengundang Bani Abdul Muttalib ke rumahnya dan menjelaskan bahwa dia telah diutus oleh Allah. Kedua, undangan terbuka kepada seluruh masyarakat quraisy di bukit Shafa. Nabi ingin melihat bagaimana pandangan masyarakat quraisy terhadap kepribadian beliau. Setelah itu beliau mengumumkan kenabiannya. Ketiga, Muhammad saw memproklamirkan ke-Esa-an Tuhan dan mengajarkan kesatuan dan persamaan antara manusia. Keempat, nabi mengadakan pertemuan khusus dengan orang-orang yang percaya kepada beliau untuk aktivitas pembacaan (tilawah), pengajaran (ta'lim), dan pensucian (tazkiyah), di rumah Arqam bin Abil Arqam, dan merupakan sekolah Islam yang pertama. Kelima, beberapa pengikut nabi meninggalkan Mekah dan mencari perlindungan atau mengungsi ke Ethiopia, sebuah negeri di seberang Laut Merah.
\end{abstract}

Kata Kunci: Metode, Materi, Kesabaran, Keteladanan

\section{A. Pendahuluan}

Secara bahasa, dakwah bermakna penyiaran, propaganda (Poerwadarminta, 1976: 222). Sedangkan dalam Ensiklopedi Islam diartikan seruan, panggilan dan undangan. Barangkali kita dapat sepakat, bahwa pemahaman dakwah Islam sebagai propaganda tidaklah tepat karena propaganda merupakan kegiatan dimana hasil akhirnya adalah untuk kepentingan orang yang membawa pesan tersebut. Sedangkan landasan dakwah bukanlah dilakukan untuk kepentingan satu golongan individu tertentu, melainkan untuk semua golongan baik minoritas maupun mayoritas (Patmawati, 2010: 7).

Secara istilah dakwah itu mempunyai defenisi yang berbeda, sejalan dengan tinjauan para ahlinya. Berikut dapat diterangkan beberapa defenisi:

Dakwah ialah suatu sistem kegiatan dari seseorang, sekelompok, segolongan umat Islam sebagai aktualisasi imaniah yang 
memanifestasikannya kepada seseorang, sekelompok massa dan masyarakat supaya dapat mempengaruhi tingkah lakunya untuk mencapai tujuan tersebut.

Menurut defenisi yang dikemukakan oleh Abu Risman, dakwah adalah segala macam usaha yang dilakukan oleh seorang muslim atau lebih untuk merangsang orang lain agar lebih memahami, meyakini dan kemudian menghayati ajaran Islam sebagai pedoman hidup dan kehidupannya.

Bahwa dakwah adalah ajakan yang dikemukakan di atas, dapat disimpulkan bahwa dakwah adalah ajakan, seruan, undangan dan doa yang dilakukan seorang muslim atau lebih yang ditujukan kepada orang lain atau kelompok dengan tujuan agar mereka memahami, menghayati serta mengamalkan ajaran Islam.

Pada kesempatan ini penulis bermaksud mendefenisikan dakwah islamiyah yaitu segala upaya yang telah dilakukan sejak oleh Rasulullah, sahabat, tabiin dan generasi seterusnya yang ditujukan kepada suatu objek, yang mana agar mereka (muslim dan muslimah atau non muslim) kembali dan menerima serta memahami akan ajaran Islam sebagai kebenaran yang mutlak.

Jika berbicara tentang "dakwah Rasulullah saw" maka serta-merta terlintas dalam pikiran kita tentang "cara" atau "teknik" bagaimana tema dakwah dapat disampaikan dan diterima, dihayati serta diamalkan oleh umat. Penerapan dakwah Rasulullah saw bersifat kondisional dan variatif. Maksudnya, dakwah yang dilakukan oleh beliau di suatu tempat belum tentu sama di tempat yang lain.

Rasulullah dalam menyampaikan pesan dakwahnya dapat menumbuhkan dan mengarahkan semangat kebangsaan, seperti yang dilakukan di Madinah melalui "Piagam Madinah", dimana salah satu isi piagam tersebut adalah memberikan jaminan kepada masyarakat untuk melaksanakan agamanya dan wajib membela keamanan Negara dari serangan luar (Badri Yatim, 2008: 26).

Kegiatan dakwah Rasulullah merupakan kelanjutan dari dakwah yang dilakukan oleh Nabi Ibrahim as sebelumnya. Beliau melakukan perbaikan secara bertahap, maksudnya ialah bahwa agama Islam tidak menghapus adat istiadat masyarakat secara sekaligus akan tetapi secara berangsur-angsur (evolusi) yang disesuaikan dengan keadaan dan waktu, sehingga orang tidak merasa keberatan (merasa berat) menerimanya, tidak pula menjadi penentangnya lebih-lebih dalam bidang hukum. 
Dakwah Nabi saw diambil dari alQuran dan sejarah para nabi. Rasulullah saw membekali diri dengan kebaikan, ketaqwaan, keikhlasan, akhlak mulia dalam membimbing sehingga menimbulkan simpati dan audien mudah menerima ajakan (ajaran Islam).

Cara berdakwah menurut konsep al-Quran terdapat dalam surat An-Nahl ayat 125 sebagai berikut:

"Seruhlah (manusia) ke jalan (agama) Tuhanmu dengan kebijakan dan pengajaran yang baik, dan bantahlah (berdebatlah) dengan jalan yang baik (Depag RI, 2012: 281).

Sedangkan menurut Asmuni Syukir (1983: 104), bahwa strategi dakwah itu secara garis besar meliputi: strategi ceramah, strategi tanya jawab, strategi debat, strategi percakapan antar pribadi, strategi demonstrasi.

Dalam makalah ini akan membahas: Dakwah Nabi Muhammad saw pada periode Mekah, strategi perjuangan dakwah Nabi Muhammad saw, dakwah Nabi Muhammad saw pada periode Madinah, respon masyarakat Madinah terhadap dakwah Nabi Muhammad saw, Fathu Mekah: peta kemenangan perjuangan umat Islam, terakhir haji wada: tanda berakhirnya dakwah Nabi Muhammad saw.

\section{B. Dakwah Nabi Muhammad saw Pada Periode Mekah}

Berbicara tentang Nabi Muhammad saw tidak terlalu mengalami kesulitan dalam hal sumber karena adanya al-Quran dan hadis. Al-Quran merupakan wahyu Allah yang diturunkan kepada Nabi Muhammad saw, setiap turunnya ayat, Nabi memerintahkan untuk ditulis. Kemurnian al-Quran terjaga juga tidak terlepas dari peranan sahabat (Abu Bakar, Umar bin Khattab dll.), untuk dibukukan dalam sebuah mushaf, disempurnakan lagi pada masa Utsman bin Affan dengan nama mushaf utsmani. Adapun hadis merupakan perkataan, perbuatan, dan persetujuan Nabi terhadap perbuatan sahabat. Jadi, hadis merupakan sumber kedua untuk mengetahui kehidupan dan ajaran Nabi Muhammad saw.

Nabi Muhammad saw lahir di Mekah tahun 571 Masehi. Beliau keturunan keluarga bangsawan Arab, yaitu Bani Hasyim dari suku quraisy, suku yang dipercayai memelihara Ka'bah yang dibangun Nabi Ibrahim dan anaknya (Ismail). Ayah nabi bernama Abdullah, adalah anak bungsu dari Abdul Muthalib. Abdullah meninggal dunia sebelum anaknya lahir. Sedang ibu nabi (Aminah) meninggal enam tahun kemudian (Jamil Ahmad, 2000: 2). Untuk lebih jelasnya dapat dilihat di bagan I. 
Bagan I. Keluarga Nabi Muhammad saw

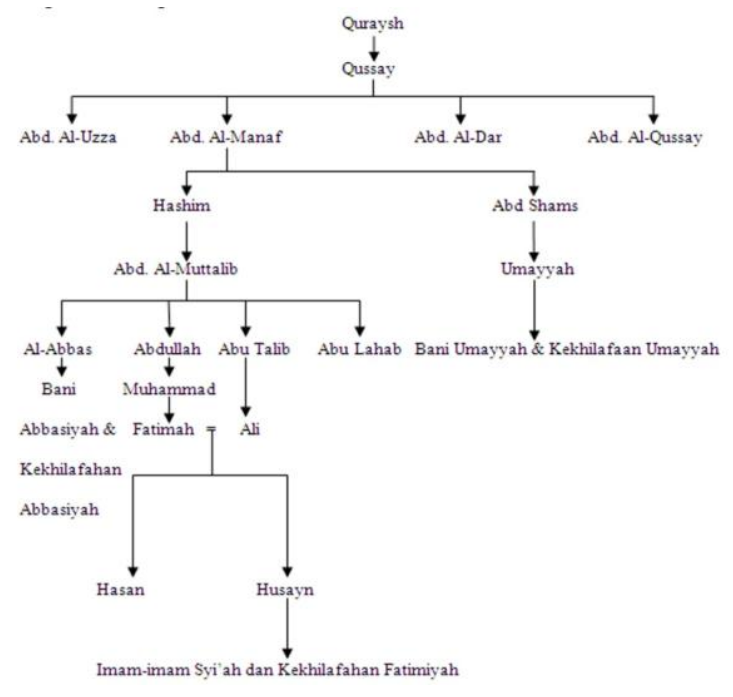

Sumber: Ira Lapidus, 1999:30

Memasuki usia yang keempat puluh, di saat dia berkontemplasi di gua Hira, tanggal 17 Ramadhan tahun $611 \mathrm{M}$, malaikat Jibril muncul dihadapannya, menyampaikan wahyu Allah yang pertama (QS. 96: 1-5): Bacalah dengan nama Tuhanmu yang telah mencipta. Dia telah menciptakan manusia dari segumpal darah. Bacalah, dan Tuhanmu itu Maha Mulia. Dia telah mengajar dengan qalam. Dia telah mengajar manusia apa yang tidak mereka ketahui.

Inilah ayat-ayat al-Quran Karim yang mula-mula diturunkan, ayatnya belum memerintahkan Nabi Muhammad menyeru manusia kepada suatu agama, dan belum pula memberitahukan kepadanya bahwa Nabi adalah utusan
Allah. Akan tetapi ayat-ayat itu mengesankan sesuatu yang luar biasa, yang belum diketahui oleh Nabi Muhammad. Itulah sebabnya maka ia segera kembali ke rumahnya dalam keadaan gemetar, apalagi ia dipeluk dengan keras oleh Jibril beberapa kali, kemudian dilepaskan dan disuruhnya membaca, seperti disebutkan di atas (A. Syalabi, 2003: 74).

Setelah turunnya wahyu yang pertama ini, Jibril tidak muncul lagi untuk beberapa lama, sementara Nabi Muhammad menantikannya dan selalu datang ke gua Hira. Dalam keadaan menanti itulah turun wahyu yang membawa perintah kepadanya. Wahyu itu berbunyi sebagai berikut: hai orang yang berselimut, bangun, dan beri ingatlah. Hendaklah engkau besarkan Tuhanmu dan bersihkanlah pakaianmu, tinggalkanlah perbuatan dosa, dan janganlah engkau memberi (dengan maksud) memperoleh (balasan) yang lebih banyak dan untuk (memenuhi perintah) Tuhanmu bersabarlah (AlMuddatsir: 1-7).

Dengan turunnya perintah itu, mulailah Rasulullah saw melakukan dakwah Islam. Langkah pertama yang dilakukan adalah berdakwah secara diam-diam di lingkungan keluarga terdekat dan di kalangan rekan-rekannya. Hal ini dapat dilihat dari firman Allah SWT 
dalam Surah Asy-Syu'ara ayat 214:"dan berilah peringatan kepada kerabatkerabatmu (Muhammad) yang terdekat". Karena itulah, orang yang pertama kali menerima dakwahnya adalah keluarga dan sahabat dekatnya, di antaranya: Khadijah (isteri), Ali bin Abi Thalib (sepupu), Abu Bakar (sahabat), Zaid ( budak yang diangkat anak), Ummu Aiman (pengasuh). Abu Bakar berhasil mengislamkan beberapa orang teman dekatnya, seperti Utsman bin Affan, Zubair bin Awwam, Abdurrahman bin Auf, Saad bin Abi Waqqas, Thalhah bin Ubaidillah dan al-Arqam bin Abi al-Arqam (Badri Yatim, 2008: 19).

Selama tiga tahun pertama sejak diutusnya Nabi Muhammad saw dakwah dilakukan secara sembunyi-sembunyi, selanjutnya dakwah dilakukan dengan terang-terangan secara lisan, misalnya memberi nasehat, memberi peringatan dsb. Hal ini dituturkan dalam QS. Al-Hijr ayat 94: "maka sampaikanlah (Muhammad) secara terang-terangan segala apa yang diperintahkan (kepadamu) dan berpalinglah dari orang yang musyrik". Sejak turunnya ayat ini, nabi mulai menyampaikan dakwah secara terbuka, sebuah langkah pertama untuk memasukkan gagasan agama ke dalam aktualisasi social dan kehidupan politik. Satu hal yang sangat penting adalah bahwasanya kelompok pengikutnya yang pertama adalah kalangan migran, kalangan miskin, warga kalan yang lemah, dan anak-anak dari kalangan klan kuat (Ali bin Abi Thalib), dimana mereka merupakan kalangan yang paling kecewa terhadap pergeseran moral dan social di Mekah, dan mereka membuktikan pesanpesan Nabi Muhammad saw sebagai sebuah alternative yang vital (Ira Lapidus, 1999: 34-35).

Adapun metode yang dilakukan nabi dalam dakwah secara terangterangan adalah: pertama, mengundang Bani Abdul Muttalib ke rumahnya dan menjelaskan bahwa dia telah diutus oleh Allah (A. Syalabi, 2003: 76), mendengar penjelasan nabi, Abu Lahab marah sambil berkata: "celakalah engkau! Apa untuk inikah kami engkau panggil?" (A. Syalabi, 2003: 76). Hal inilah yang melatarbelakangi turunnya Surah AlLahab. Kedua, undangan terbuka kepada seluruh masyarakat quraisy di bukit Shafa. Nabi ingin melihat bagaimana pandangan masyarakat quraisy terhadap kepribadian beliau. Masyarakat quraisy sepakat bahwa beliau adalah orang yang tak pernah berdusta. Setelah itu beliau mengumumkan kenabiannya (Wahyu Ilahi dan Harjani Hefni, 2007:50). Ketiga, Muhammad saw memproklamirkan keEsa-an Tuhan dan mengajarkan kesatuan dan persamaan antara manusia (Jamil Ahmad, 2000: 3). Keempat, nabi 
mengadakan pertemuan khusus dengan orang-orang yang percaya kepada beliau untuk aktivitas pembacaan (tilawah), pengajaran (ta'lim), dan pensucian (tazkiyah), di rumah Arqam bin Abil Arqam, dan merupakan sekolah Islam yang pertama. Kelima, beberapa pengikut nabi meninggalkan Mekah dan mencari perlindungan atau mengungsi ke Ethiopia, sebuah negeri di seberang Laut Merah (Bernard, 2000: 79).

Setelah dakwah secara terangterangan, pemimpin quraisy mulai berusaha menghalangi dakwah Rasul. Semakin bertambah jumlah pengikut nabi, semakin keras tantangan yang dilancarkan kaum quraisy. Menurut Ahmad Syalabi (2003: 77-80), ada lima factor yang mendorong orang quraisy menentang seruan itu: 1) persaingan berebut kekuasaan. Mereka mengira tunduk kepada agama Muhammad berarti tunduk kepada kekuasaan Bani Abdul Muttalib. Sedang suku-suku bangsa Arab selalu bersaing untuk merebut kekuasaan dan pengaruh. 2) penyamaan hak antara kasta bangsawan dan kasta hamba sahaya. Bangsa Arab hidup berkastakasta. Tiap-tiap manusia digolongkan kepada kasta yang tak boleh dilampauinya. Tetapi, seruan Nabi Muhammad memberikan hak sama kepada manusia. 3) takut dibangkit. Agama Islam mengajarkan bahwa pada hari kiamat manusia akan dibangkit dari kuburnya, dan bahwa semua perbuatan manusia akan dihisab. 4) taklid kepada nenek moyang. Taklid kepada nenek moyang secara membabi buta, dan mengikuti langkah-langkah mereka dalam soal-soal peribadatan dan pergaulan adalah suatu kebiasaan yang berurat berakar pada bangsa Arab. 5) memperniagakan patung. Ini adalah satu sebab materi. Salah satu dari perusahaan orang Arab zaman dahulu, ialah memahat patung yang menggambarkan al-Lata, alUzza, Manah dan Hubal. Patung-patung itu mereka jual kepada Jemaah-jemaah haji.

Kaum quraisy selalu berusaha untuk menumpas dan menindas agama Islam dengan menempuh jalan apa saja (H. Munzier Suparta \& Harjani Hefni, 2003: 48), salah satunya dengan memboikot Bani Hasyim. Isi piagam pemboikotan tersebut antara lain: mereka memutuskan segala bentuk hubungan dengan Bani Hasyim seperti pernikahan, silaturrahmi dan jual beli (Badri Yatim, 2008: 23).

\section{Strategi Perjuangan Dakwah Nabi Muhammad saw}

Selama tahun-tahun pertama masa kenabian, Nabi Muhammad saw mendapatkan sejumlah pengikut, mulamula dari anggota keluarganya sendiri, 
dan kemudian dari lingkungan masyarakat yang agak luas. Lambat laun, gagasan-gagasan baru dan tindakantindakan baru yang mereka lakukan itu menimbulkan kecurigaan dan mendapat perlawanan dari kalangan keluarga yang terkemuka di Mekah. Mereka memandang Nabi Muhammad saw dan ajaran yang disebarkannya sebagai ancaman terhadap kedudukan mereka sendiri. Kaum quraisy melakukan tekanan-tekanan, dan bahkan penyiksaan terhadap beberapa pengikut nabi yang baru masuk Islam (Bernard, 2000:79). Hal inilah yang membuat nabi melakukan beberapa strategi, di antaranya:

\section{Hijrah ke Habsyi}

Pada tahun 615, tanda-tanda kongkrit bahwa Nabi Muhammad akan menjadi pimpinan komunitas baru berdasarkan ajarannya, dan terlepas dari komunitas Mekah lainnya. Bulan ketujuh tahun kelima kenabian berangkatlah 11 orang laki-laki beserta 4 wanita. Kemudian rombongan berikut menyusul hingga jumlah yang hijrah ke Habsyi mencapai 70 orang. Di antaranya adalah Utsman bin Affan dan istrerinya (Ruqayyah puteri Nabi Muhammad saw), Zubair bin Awwam, Abdurrahman bin Auf, Ja'far bin Abi Thalib, dan lain-lain. Mereka melakukan hijrah untuk mengamankan agama yang baru mereka anut, bahkan bersedia melepaskan keluarga dalam rangka membentuk kehidupan bersama di sebuah negeri asing. Ikatan keagamaan ini lebih kuat daripada ikatan darah. Dengan cara demikian, agama baru tersebut mengancam tata kemasyarakatan yang lama sekaligus menggantinya dengan tata kemasyarakatan yang baru (Rianawati, 2010: 33).

Kedatangan orang-orang Islam di Habsyi disambut dengan baik oleh Raja Nejus. Bahkan ia memberikan perlindungan dan diizinkan untuk melaksanakan ibadah Islam. Dia juga menolak permintaan suku quraisy supaya mengembalikan orang-orang mukmin ke Mekah.

Di saat pengikut nabi hijrah ke Habsyi, dia tetap berada di Mekah untuk berdakwah. Dia mendapat perlindungan dari Bani Hasyim. Bahkan dua orang tokoh quraisy masuk ke dalam Islam yakni Hamzah bin Abdul Muttalib dan Umar bin Khattab.

Masuknya Umar ke dalam Islam, dimana awalnya dia adalah musuh Islam yang sangat kuat. Diceritakan bahwa sewaktu Umar akan pergi mencari Nabi untuk membunuhnya. Di tengah jalan dia berjumpa dengan Naim bin Abdullah dan menanyakan tujuan kepergian Umar. Umar lalu menceritakan tentang 
keputusannya membunuh nabi. Dengan mengejek Naim mengatakan agar Umar lebih baik memperbaiki urusan rumah tangganya lebih dahulu. Seketika itu juga Umar kembali ke rumah dan mendapati iparnya sedang asyik membaca al-Quran. Umar marah dan memukul sang ipar dengan ganas. Kejadian itu tidak membuat ipar dan adiknya meninggalkan Islam. Sehingga Umar meminta dibacakan kembali al-Quran tersebut. Kandungan arti dan alunan ayat-ayat Kitabullah ternyata membuat Umar begitu terpesona, sehingga ia bergegas ke rumah nabi dan langsung memeluk agama Islam.

\section{Pergi Ke Thaif}

Tahun kesepuluh kenabian dikenal dengan tahun duka bagi Nabi Muhammad saw, sebab 2 orang yang sangat dicintainya telah meninggal dunia, yaitu Siti Khadijah dan Abu Thalib. Kedua orang ini adalah pembela dan pelindung yang sangat tabah, kuat dan disegani masyarakat Mekah. Dengan meninggalnya Siti Khadijah dan Abu Thalib, orang-orang kafir quraisy semakin berani mengganggu dan menyakiti Nabi Muhammad saw, karena penderitaan yang dialami Nabi Muhammad saw semakin hebat, maka ia berencana memperluas wilayah dakwahnya di luar
Mekah (Siti Muriah, 2000: 35) seperti ke Thaif. Beliau melakukan perjalanan ke Thaif ditemani oleh Zaid bin Haritsah. Kepergiannya ke Thaif untuk menyebarkan Islam kepada pembesarpembesar dan kepala-kepala suku di tempat tersebut.

Nabi berharap dakwahnya diterima masyarakat Thaif, akan tetapi, harapan tersebut tidak menjadi kenyataan, bahkan beliau diusir dan dihina dengan cara-cara yang tidak manusiawi. Beliau diusir dan dilempari batu oleh para pemuda Kota Thaif. Mereka tidak mau mengambil resiko, karena mereka pasti akan mendapatkan perlakuan yang tidak baik dari masyarakat Mekah bila menerima Islam sebagai agama baru mereka. Para pembesar Kota Thaif menganggap Muhammad adalah orang gila yang terusir dari Mekah, berdasarkan informasi yang mereka terima dari Abu Jahal, bahwa apa yang diajarkan Muhammad adalah kebohongan besar yang akan menyesatkan bangsa Arab.

\section{Perjanjian Aqabah}

Perjanjian Aqabah di awali dengan dakwah yang dilakukan Nabi terhadap orang-orang Yastrib yang datang ke Mekah pada musim haji. Sebagian mereka menerima seruan Nabi dan 
masuk ke dalam Islam. Peristiwa ini merupakan titik terang dalam perjalanan dakwah nabi, karena penerimaan masyarakat Yastrib terhadap misi yang disampaikannya membuka lembaran baru dalam usaha beliau menyampaikan ajaran Islam.

Akhirnya terjadilah perjanjian Aqabah I pada tahun 621 dan setahun kemudian diadakan perjanjian Aqabah II. Isi perjanjian tersebut, mereka mengundang nabi dan para pengikutnya datang dan tinggal di kota mereka, dan bahkan menjadikan nabi sebagai penengah dan juru damai dalam pertikaian-pertikaian yang terjadi di antara mereka. Mereka juga menyatakan kesanggupan membela nabi dan para pengikutnya dan menyertai beliau pindah dari Mekah ke kota mereka, sebagaimana halnya mereka membela warga mereka sendiri.

Dari perjanjian ini, nabi mengirimkan kira-kira 60 keluarga ke Yastrib terlebih dahulu, kemudian nabi menyusul mereka ke Yastrib. Kepindahan nabi dan para pengikutnya dari Kota Mekah ke Yastrib, dalam bahasa Arab dikenal hijrah, yang secara harfiah berarti migrasi atau berpindah, peristiwa ini sangat menentukan sejarah kerasulan Muhammad, bahkan penanggalan hijriah diambil dari peristiwa ini. Kota Yastrib menjadi pusat keagamaan dan komunitas muslim, nama Yastrib berubah menjadi al-madinah yang berarti kota. Komunitas muslim disebut ummat yang berarti masyarakat (Bernard Lewis, 2010: 80).

Di Mekah Muhammad merupakan pribadi biasa yang berjuang melawan ketidakacuhan atau ketidakpedulian yang ada di lingkungannya, dan kemudian juga melawan sikap permusuhan dari golongan yang berkuasa. Masyarakat Mekah pada waktu itu terbagi atas dua bagian besar, golongan merdeka dan golongan budak belian (al-hurr wal-abd). Dalam hal kekayaan, mereka terbagi dua, orang kaya dan orang miskin (al-aghniya wal-fuqara). Dalam kekuatan politik, mereka hanya mengenal yang kuat dan yang lemah (al-mala wal-dhu'afa). Status social sedemikian pentingnya, sehingga budak belian bukan saja tak dianggap sebagai manusia, melainkan diperjualbelikan seperti binatang, sehingga melahirkan bayi wanita dianggap aib yang luarbiasa. Dilukiskan di dalam al-Quran: "ingatlah ketika anak perempuan itu ditanya dosa apa (yang mereka lakukan, sehingga) mereka dibunuh?" (QS. 81: 8-9).

\section{Dakwah Nabi Muhammad saw Pada Periode Madinah}

Madinah dianggap sebagai kelahiran baru agama Islam setelah ruang dakwah di Mekah terasa sempit bagi 
kaum muslimin. Allah SWT memilih Madinah sebagai pilot project pembentukan masyarakat Islam pertama. Madinah memang layak dijadikan kawasan percontohan (Wahyu llaihi \& Harjani Hefni, 2007: 55). Berawal dari respon orang-orang Yastrib yang datang ke Mekah pada bulan haji terhadap seruan nabi, juga tidak terlepas dari pribadi nabi yang dikenal sebagai orang yang tak pernah berbohong.

Keberhasilan dakwah nabi dapat dilihat pada sikap orang-orang Yastrib di perjanjian Aqabah I dan II, dimana mereka mau mengubah sikap dan perilaku mereka, bahkan bersedia menjadi pelindung nabi. Sebab dakwah pada hakekatnya merupakan suatu upaya seorang dai dan sekaligus juga sebagai media untuk mengubah perilaku masyarakat dari yang negative menjadi positif atau berakhlak mulia, tertinggal menjadi maju serta bodoh menjadi pandai (M. Bahri Ghazali, 1997: 1). Inilah yang dilakukan Nabi terhadap masyarakat Yastrib, membentuk suatu masyarakat baru, dan meletakkan dasar-dasar untuk suatu masyarakat yang besar yang sedang ditunggu oleh sejarah. Dalam mewujudkan semua ini, nabi menempuh langkah-langkah dakwah sebagai berikut:
Pertama: Membangun masjid

Waktu Rasulullah saw masuk Madinah, penduduk Madinah yang sudah memeluk Islam (kaum Anshar) banyak yang mengundang serta menawarkan rumah untuk beristrahat. Setelah nabi sampai di tanah milik kedua orang anak yatim bernama Sahal dan Suhail keduanya anak Amr bin Amarah dibawah asuhan Mu'adz bin 'Afra, berhentilah unta yang ditunggangi nabi, kemudian beliau dipersilahkan oleh Abu Ayub Anshari untuk tinggal di rumahnya.

Setelah beberapa bulan nabi di situ maka beliau membangun Masjid Nabawi pada sebuah tanah milik kedua anak yatim tersebut, tanah itu dibeli oleh nabi untuk pembangunan masjid, juga untuk tempat tinggal. Masjid yang di bangun tersebut berfungsi sebagai tempat melaksanakan ibadah shalat. Dalam kesempatan ini nabi dan para pengikutnya berdiri bahu-membahu, mengajarkan keuntungan yang tak terkirakan dari persaudaraan, dan menanamkan semangat persamaan antar manusia (Jamil Ahmad, 2000: 4). Masjid juga sebagai sarana penting untuk mempersatukan kaum muslimin dan mempertalikan jiwa mereka, di samping sebagai tempat bermusyawarah merundingkan masalah-masalah yang dihadapi, masjid pada masa Nabi bahkan 
juga berfungsi sebagai pusat pemerintahan (Badri Yatim, 2008: 26).

Kedua: Menciptakan persaudaraan baru

Kaum muslimin yang berhijrah dari Mekah ke Madinah disebut "muhajirin" dan kaum muslimin penduduk Madinah disebut "anshor". Kaum muslimin Mekah yang berhijrah ke Madinah banyak menderita kemiskinan, karena harta benda dan kekayaan mereka ditinggalkan di Mekah, diwaktu mereka berhijrah ke Madinah melarikan agama dan keyakinan yang mereka anut.

Nabi Muhammad saw menciptakan persaudaraan baru antara kaum muhajirin dengan kaum anshor. Ali ibn Abi Thalib dipilih menjadi saudara nabi sendiri. Abu Bakar nabi saudarakan dengan Kharijah ibnu Zuhair. Ja'far ibnu Abi Thalib dengan Mu'az ibnu Jabal. Rasulullah telah mempertalikan keluargakeluarga Islam. Masing-masing keluarga mempunyai pertalian yang erat dengan keluarga-keluarga yang banyak, karena ikatan persaudaraan yang diadakan rasulullah. Persaudaraan ini pada permulaannya mempunyai kekuatan dan akibat sebagai yang dipunyai oleh persaudaraan nasab, termasuk di antaranya hal pusaka, hal tolong menolong dan lain-lain (A. Syalabi, 2003: 103).
Ketiga: Perjanjian dengan masyarakat Yahudi Madinah

Setelah mempersaudarakan antara kaum muhajirin dengan anshor, selanjutnya nabi menjalin hubungan antara kaum muslim dengan golongan Yahudi penduduk Madinah. Jalinan hubungan ini terwujud dalam bentuk perjanjian atau undang-undang yang kemudian dikenal sebagai "Piagam Madinah" yang ditulis pada tahun $623 \mathrm{M}$ atau tahun ke-2 $\mathrm{H}$. di antara dictum perjanjian paling penting adalah sebagai berikut:

- Kaum muslimin dan kaum Yahudi hidup secara damai, bebas memeluk dan menjalankan ajaran agamanya masing-masing.

- Orang-orang Yahudi berkewajiban memikul biaya mereka sendiri, dan kaum muslimin wajib memikul biaya mereka sendiri.

- Apabila salah satu pihak diperangi musuh, maka mereka wajib membantu pihak yang diserang.

- Di antara mereka saling mengingatkan, dan saling berbuat kebaikan, serta tidak akan saling berbuat kejahatan.

- Kaum muslimin dan Yahudi wajib saling menolong dalam melaksanakan kewajiban untuk kepentingan bersama. 
- Bumi Yastrib menjadi tanah suci karena naskah perjanjian ini.

- Nabi Muhammad adalah pemimpin umum untuk seluruh penduduk Madinah. Bila terjadi perselisihan di antara kaum muslimin dengan kaum Yahudi, maka penyelesaiannya dikembalikan kepada nabi sebagai pemimpin tertinggi di Madinah (Wahyu Ilaihi \& Harjani Hefni, 2007: 59).

Nabi berhasil membangun sebuah Negara baru yakni Negara Madinah, secara aklamasi nabi diangkat sebagai kepala Negara yang diberikan otoritas untuk memimpin dan melaksanakan ketatanegaraan yang telah disepakati bersama. Jadi, di Madinah beliau seorang penguasa, yang menjalankan kekuasaan politik dan militer dan juga keagamaan (Bernard Lewis, 2010: 80).

Keempat: Pembangunan pranata sosial dan pemerintahan.

$$
\text { Madinah adalah wilayah }
$$
pertanian, dihuni oleh berbagai klan dan tidak oleh sebuah kesukuan yang tunggal, namun berbeda dengan Mekah, Madinah merupakan perkampungan yang diributkan oleh permusuhan yang sengit dan anarkhis antara kelompok kesukuan yang terpandang -Suku Aws dan Khazraj. Permusuhan yang berkepanjangan mengancam keamanan rakyat kecil dan mendukung timbulnya permasalahan eksistensi Madinah. Berbeda dengan masyarakat Badui, masyarakat Madinah telah hidup saling bertetangga dan tidak berpindah dari tempat satu ke tempat lainnya. Selanjutnya berbeda dengan Mekah, Madinah senantiasa mengalami perubahan social yang meninggalkan bentuk kemasyarakatan absolut model Badui. Kehidupan sosial Madinah secara berangsur-angsur diwarnai oleh unsur kedekatan ruang daripada oleh system kekerabatan. Madinah juga memiliki sejumlah warga Yahudi, yang mana sebagian besar penduduknya lebih simpatik terhadap monotheisme (Ira. M. Lapidus, 1999: 38). Namun setelah masyarakat muslim berkembang menjadi besar dan berkuasa, mereka mulai menaruh rasa dendam dan tidak suka.

Islam di Madinah bukan hanya sebuah agama, tetapi juga mengatur Negara. Karena masyarakat Islam telah terwujud, maka menjadi suatu keharusan Islam untuk menentukan dasar-dasar yang kuat bagi masyarakat yang baru terwujud itu. Sebab itu ayat-ayat al-Quran yang diturunkan dalam periode ini terutama ditujukan kepada pembinaan hukum. Ayat-ayat yang diturunkan itu diberi penjelasan oleh rasulullah. Manamana yang belum jelas dan belum terperinci dijelaskan oleh rasulullah 
dengan perbuatan-perbuatan beliau (A. Syalabi, 2003: 104).

Islam yang diturunkan oleh Allah SWT ke muka bumi melalui perantaraan kenabian Muhammad saw, ditujukan sebagai pedoman bagi kehidupan di dunia dan akhirat. Islam mengembang amanat untuk memerdekakan manusia dari segala perbudakan dan membebaskan manusia dari segala penindasan. Islam tidak mengenal batasbatas suku, keturunan, tempat tinggal, atau jenis kelamin. Semua umat manusia, dalam pandangan Islam, mempunyai kedudukan setara. Sebab, kemuliaan kedudukan manusia dalam Islam tergantung dari kwalitas ketaqwaannya pada Allah SWT atau amal salehnya. Tentu saja kwalitas ketaqwaan atau amal saleh ini tidak hanya diukur dengan perilaku vertical kepada Tuhannya, namun juga akhlak horizontal kepada sesama manusia. Sesuai dengan firman Tuhan al-Hujurat: 13: "hai manusia, sesungguhnya kami jadikan kamu bersaldari laki-laki dan perempuan, dan kami jadikan kamu berbangsa-bangsa dan bersuku-suku agar kamu berkenalkenalan, sesungguhnya orang yang termulia di antaramu pada sisi Allah ialah orang yang lebih taqwa".

\section{E. Respon Masyarakat Madinah Terhadap Dakwah Nabi Muhammad Saw}

Sesudah peristiwa hijrah, penduduk Madinah terdiri atas tiga golongan: kaum muslimin, bangsa Yahudi (Banu Nadhir dan Banu Quraizhah) dan bangsa Arab yang belum menganut agama Islam (A. Syalabi, 2003: 104). Kepada ketiga golongan tersebut, nabi terus berusaha menyebarkan agama Islam. Hal itu dilakukan nabi saw selain karena kewajiban yang harus dilaksanakannya, juga karena ia melihat mayoritas masyarakat Madinah menyambut dengan baik saat beliau dan umat Islam tiba di kota tersebut.

Pada hakekatnya dakwah nabi merupakan aktualisasi imani yang dimanifestasikan dalam suatu sistem kegiatan, dalam bidang kemasyarakatan yang dilaksanakan secara teratur, untuk mempengaruhi cara merasa, berfikir, bersikap, dan bertindak masyarakat Madinah, dengan menggunakan cara tertentu. Dakwah nabi berusaha mengubah lingkungan Madinah dengan cara meletakkan dasar eksistensi masyarakat Islam, menanamkan nilai-nilai keadilan, persamaan, persatuan, perdamaian, kebaikan, dan keindahan, sebagai inti penggerak perkembangan masyarakat, membebaskan individu dari sistem kehidupan zalim (perbudakan) 
menuju sistem kemerdekaan, menyampaikan kritik sosial atas penyimpangan yang berlaku dalam masyarakat Madinah, dalam rangka mengembang tugas nahi mungkar, dan memberi alternative konsepsi atas kemacetan sistem, dalam rangka melaksanakan amar ma'ruf, merealisasi sistem budaya yang berakar pada dimensi spiritual yang merupakan dasar ekspresi akidah, meningkatkan kesadaran masyarakat Madinah untuk menegakkan hukum, mengintegrasikan kelompokkelompok kecil (muslim, Yahudi, bangsa Arab non muslim) menjadi suatu kesatuan kekuatan untuk mengamankan Negara Madinah dari serangan luar, merealisasi keadilan dalam bidang ekonomi, dengan mempersaudarakan golongan aghniyaa (anshor) dengan golongan ekonomi lemah (muhajirin) (Didin Hafidhuddin, 1998: 67-68).

Dakwah yang dilakukan nabi mendapat sambutan beragam, ada yang menerima kemudian masuk Islam dan ada pula yang menolak secara diamdiam, misalnya, orang-orang Yahudi yang tidak senang atas kehadiran nabi dan umat Islam. penolakan ini mereka lakukan secara diam-diam dan tidak berani berterus terang untuk menantang nabi dan umat Islam yang mayoritas tersebut. Kedengkian orang-orang Yahudi semakin menjadi-jadi, sewaktu mereka menyaksikan sendiri perkembangan pesat agama yang dibawa nabi, seakanakan jalan untuk mencapai kemenangan telah terhampar datar (A. Syalabi, 2003: 115). Apalagi sekutu mereka (suku Aus dan Khazraj) setelah memeluk Islam, sudah tak membutuhkan mereka lagi, karena telah mendapat pimpinan yang ideal yakni Muhammad saw.

Akhirnya Yahudi Madinah menggalang koalisi dengan kafir Quraisy Mekah, untuk menghancurkan kekuatan umat Islam. bahkan peperangan terjadi antara kaum muslim Madinah dengan musyrik quraisy Mekah. Perang pertama yang sangat menentukan masa depan negara Islam ini adalah perang Badar pada tanggal 8 Ramadhan tahun ke 2 Hijriah, nabi bersama 305 orang muslim bergerak keluar kota membawa perlengkapan yang sederhana. Di daerah Badar, kurang lebih 120 kilometer dari Madinah, pasukan nabi bertemu dengan pasukan quraisy yang berjumlah sekitar 900 sampai 1000 orang. Nabi sendiri yang memegang komando. Dalam perang ini kaum muslimin keluar sebagai pemenang (Badri Yatim, 2008: 27).

Dalam beberapa tahun berikutnya, pihak Quraisy Mekah menyerang pihak Muhammad di Madinah. Sehingga terjadi lagi peperangan, yakni perang Uhud (625) dan kemudian disusul perang Khandak (627). Dalam perang Uhud, 
pihak Muhammad menderita kekalahan, sedang dalam perang Khandaq pihak Muhammad berhasil menghancurkan dan membuat kecewa pihak Mekah, pihak Muhammad diuntungkan dalam kedua peperangan tersebut. la berhasil bertahan dari serangan yang dilancarkan pihak Mekah, dan bahkan pada setiap kesempatan menyusun rencana pengusiran atau penghukuman terhadap sisa-sisa klan Yahudi, merampas kekayaan mereka dan memperluas pengaruh dirinya terhadap suku-suku di padang pasir di Arabia (Ira M. Lapidus, 1999: 47). Setelah enam tahun meninggalkan Mekah, mereka ingin kembali mengunjungi kampung halamannya untuk bertemu dengan kerabat, dan menziarahi Ka'bah. Namun keinginan mereka tak dapat terpenuhi, sehingga terjadilah Perjanjian Hudaibiah. Perjanjian Hudaibiah ini memperlihatkan bahwa suku Quraisy yang ada di Mekah sudah mengakui nabi Muhammad sebagai pemimpin negara Madinah. Sebuah perjanjian baru terjadi apabila ada pengakuan setara dengan kedua belah pihak. Memasuki tahun ke-8 $\mathrm{H}$ terjadi perang Mu'tah yang disebabkan utusan (Al-Harits ibnu Umar al-Azdi) yang dikirim nabi kepada Ghasasinah (Bani Ghassan) dibunuh oleh mereka. perang Mu'tah merupakan cikal bakal perluasan Islam keluar Jazirah Arab. Pada tahun yang sama terjadi peperangan menaklukkan kota Mekah, peristiwa ini disebabkan pengkhianatan Quraisy terhadap perjanjian yang telah dibuat antara Quraisy dengan kaum Muslimin. Pada kejadian ini umat Islam menang tanpa terjadi pertumpahan darah, bahkan Abbas dan Abu Sufyan menyatakan keislamannya. Takluknya kota Mekah membuat delegasi dari berbagai penjuru di Jazirah Arab mendatangi nabi sehingga tahun ke-9 H dianggap sebagai tahun delegasi. Agama Islam telah meratai seluruh Jazirah Arab, nabi Muhammad telah merasakan kenikmatan yang tak terhingga, dia telah menyaksikan sendiri dakwah yang dilaksanakan telah berbuah. Bahkan ini dianggap sebagai asbabun nuzulnya Surat an Nashr. Pada tahun 10 H Nabi mengerjakan haji terakhir, yang dikenal dalam sejarah dengan "Hijjatul Wada".

\section{F. Kesimpulan}

Nabi Muhammad adalah nabi terakhir yang diutus oleh Allah SWT beliau berasal dari nasab yang mulia dari keturunan Nabi Ismail bin Ibrahim. Muhammad kecil tinggal di sebuah desa yang jauh dari pengaruh kota, alam yang segar, dan Susana yang serba alami, dibawah asuhan Halimah di perkampungan bani Sa'ad. Hidup dalam 
keprihatinan, ditinggal bapak sejak masih dalam kandungan, setelah itu ditinggal pula ibunya, dan selanjutnya oleh kakeknya yang begitu menyayanginya. Latihan kesabaran dengan mengembala kambing, berperan aktif dalam kegiatan di masyarakat sejak kecil, menimba pengalaman internasional (ikut armada dagang suku Quraisy), tidak pernah cacat di masyarakatnya, memiliki prestasi yang diakui oleh umatnya sejak usia belia, menjelang usia 40 tahun secara intensif melakukan perenungan tentang hakikat kehidupan.Materi dakwah nabi di Mekah meliputi tauhid, iman kepada hari kiamat, pembersihan jiwa dari segala kemungkaran dan kekejian. Metode dakwah nabi di Mekah, yakni secara rahasia, terang-terangan, dakwah keluar wilayah Mekah. Sarana dakwah nabi di Mekah, ada dua: pertama, sarana fisik, meliputi: Masjidilharam, Bukit Shafa, rumah, tabligh terbuka, dakwah bil hal, melakukan ta'akhi (mempersaudarakan sesama muslim). Kedua, sarana non fisik, meliputi: Hubungan Rasulullah dengan Allah, kejujuran dan kepribadian Rasulullah yang luhur, kehati-hatian dan kewaspadaan, dan menerapkan strategi dan sistem yang tertata baik.

Dakwah Nabi Muhammad saw di Madinah, diawali dengan hijrah sebagai metode dakwah. Negara Madinah dijadikan sarana baru dakwah Rasulullah, dengan mendirikan mesjid dan menjalin persatuan sesama muslim, turunnya perintah jihad, dakwah dengn mengirim duta dan surat, nabi dan peperangan, akhirnya masyarakat Madinah dibawah naungan Syariat Islam. Ciri-ciri dakwah di Madinah: menjaga kesinambungan tarbiyah dan tazkiyah bagi sahabat yang telah memeluk Islam, mendirikan daulah Islamiyah, adanya keseriusan untuk menerapkan hukum syariat, hidup berdampingan dengan agama lain, menghadapi secara tegas pihak yang memilih perang, merealisasikan universalitas dakwah Islam, melalui surat, mengirm duta, mengirim rombongan, dan menerima utusan yang datang.

\section{G. Daftar Pustaka}

A.Syalabi, Sejarah dan Kebudayaan Islam I, Jakarta: Pustaka al-Husna, 2003.

Amrullah Ahmad, Dakwah Islam dan Perubahan Sosial, Yogyakarta: Yafi, 1983.

Asmuni Syukir, Dasar-dasar Strategi Dakwah Islam, Surabaya: al-Ikhlas, 1983.

Badri Yatim, Sejarah Peradaban Islam, Jakarta: Rajawali Press, 1993.

Bernard Lewis, The Middle East, diterjemahkan oleh Abd. Rachman 
Abror, Pontianak: STAIN Press, 2010.

Departeman Agama RI, Al-Qur'an dan

Terjemahnya, Jakarta: WALI, 2012.

Didin Hafidhuddin, Dakwah Aktual, Jakarta: Gema Insani Press, 1998.

H.Munzier Suparto dan Harjani Hefni, Metode Dakwah, Jakarta: Prenada Media, 2003.

Ira M. Lapidus, A History of Islamic Sicieties, diterjemahkan oleh Ghufron A. Mas'adi, dengan judul "Sejarah Sosial Ummat Islam", Jakarta: Raja Grafindo Persada, 1999.

Jamil Ahmad, Hundred Great Muslims, diterjemahkan oleh Tim Penerjemah Pustaka Firdaus dengan judul "Seratus Muslim Terkemuka", Jakarta: Pustaka Firdaus, 2000.

M. Bahri Ghazali, Da'wah Komunikatif Membangun Kerangka Dasar IImu Komunikasi Dakwah, Jakarta: Pedoman IImu Jaya, 1997.

Patmawati, Laporan Penelitian, "Pembenahan Strategi Dakwah Melalui Individual and Group Converence", Pontianak: STAIN Pontianak, 2010.

Rianawati, Sejarah Peradaban Islam, Pontianak: STAIN Press, 2010.

Wahyu Ilahi dan Harjani Hefni, Sejarah Dakwah, Jakarta: Rahmat Semesta, 2007.
W.J.S. Poerwadarminta, Kamus Umum Bahasa Indonesia, Jakarta: Balai Pustaka, 1976. 